\title{
2011 margójára A területi kérdések iránt érdeklődő szakemberek összefogása
}

\section{Some editorial notes on 2011}

Nehéz évet zártunk a Tér és Társadalom folyóiratnál. Az elmúlt év folyamán hat számot jelentettünk meg, ebből kettő szám még az előző szerkesztőséghez tartozott, az újonnan alakult szerkesztőség pedig elkészítette a rá háruló négy számot. A szokatlanul nagy feladat teljesítése a regionális szakma és a hozzá alkalmanként csatlakozók összefogásával volt csak lehetséges: a 2011/1-4 számhoz közel 90 tanulmány érkezett, amelyek lektorálásában több mint kilencvenen vettek részt. Ezek az elismerésre okot adó számok is azt igazolják, hogy az elmúlt 25 évben a regionális tudomány fontos és kiterjedt tudományterületté vált Magyarországon.

A szerkesztőbizottság néhány alapvető változást vezetett be 2011-ben. A folyóiratban nagyobb teret szán az elméleti kérdésekkel foglalkozó és vitatkozó tanulmányoknak. A nemzetközi nyitást egyrészt a határon túli szerkesztőbizottsági tagok aktív részvételével, másrészt a tanulmányokhoz füzött részletezőbb angol nyelvű absztraktok megjelentetésével valósítottuk meg.

A folyóirat színvonalát a korábbinál szigorúbb lektori véleményezéssel kívántuk emelni. A lektorok elismerésre méltó szakmai felelősséggel végezték munkájukat, nekik köszönhető, hogy valóban a nívósabb írások kerültek a publikációk közé (a beküldött tanulmányok egyharmadát utasították el, és a másik harmadát jelentős változtatások, javítások után támogatták). E számunk végén adjuk közre a 2011-ben megjelent tanulmányok szerzőinek és a beküldött tanulmányokhoz felkért lektoroknak a listáját (minden tanulmányhoz két lektortól kértünk véleményt, és gyakran előfordult, hogy egy-egy szakértő többször is vállalta a lektori teendőket). Ugyancsak mérföldkőnek tekinthető a TéT weboldalán - kissé késleltetve - olvasható tanulmányok megjelenése, valamint a digitális rendszerbe szervezett, átlátható lektorálási-szerkesztési procedúra bevezetése.

A TéT ma már annak a Közgazdaság- és Regionális Tudományi Kutatóközpontnak a folyóirata, amelybe az RKK integrálódott. Az előfizetések jelenleg szűken egy szám finanszírozását fedezik az évi négyből. A Tér és Társadalom azonban - szerzőinek kutatóhelyeit tekintve - országos léptékűvé vált; szakmánk közös érdeke, hogy a folyóirat a továbbiakban is megjelenjen. Hasznos lenne az összefogás e téren is.

Köszönjük a szerzők, lektorok színvonalas munkáját és olvasóink töretlen érdeklődését! 


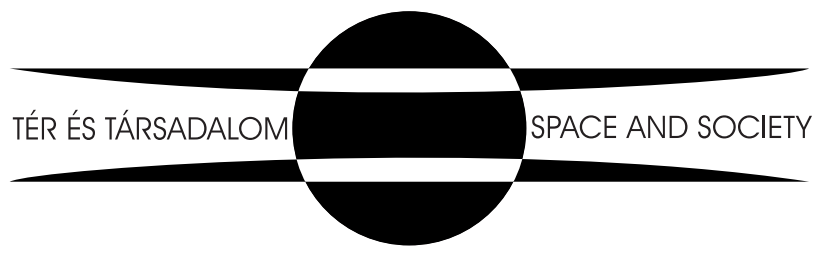

